TRENDS IN HYDROZOAN BIOLOGY - IV. C.E. MILLS, F. BOERO, A. MIGOTTO and J.M. GILI (eds.)

\title{
A new species of Pachycordyle (Hydrozoa, Clavidae) from Lake Biwa (Japan), with remarks on this and related Clavid genera*
}

\author{
SOFIA D. STEPANJANTS ${ }^{1}$, OLEG A. TIMOSHKIN ${ }^{2,3}$, BORIS A. ANOKHIN ${ }^{1}$ \\ and TATIANA O. NAPARA ${ }^{4}$ \\ ${ }^{1}$ Zoological Institute of the Russian Academy of Sciences, 199034 St.Petersburg, Russia. \\ ${ }^{2}$ Center for Ecological Research, Kyoto Universitat. 509-3 Otsuka Kamai-Tanakami Otsu 520-2113, Japan. \\ ${ }^{3}$ Limnological Institute of the Siberian Branch of the Russian Academy of Sciences, Ul. Ulan-Batorskaya, 3 , \\ P.O.Box 4199, 664033 Irkutsk, Russia. \\ ${ }^{4}$ Institute of Cytology of the Russian Academy of Sciences, 194064 St.Petersburg, Russia.
}

\begin{abstract}
SUMMARY: The history of research on species of Pachycordyle and related genera is discussed. A description and differential diagnosis of a new species, Pachycordyle kubotai, is presented. Hydroid colonies, hydranths, and gonophores of this species are described in detail. Peculiarities of medusoid development and oocyte maturation are analyzed. The genus Pachycordyle is rediagnosed and an identification key to species assigned to it is provided. Clavopsella is regarded as congeneric with Pachycordyle. Thieliana is established as a new genus for species subsequently and erroneously assigned to Clavopsella. The taxonomic status of species referable to Thieliana is discussed. Justification is provided for our position that these genera belong to the family Clavidae. Characteristics of genera assigned to the family Clavidae are summarized. Data on the geographic distribution and ecology of the species of Cordylophora, Pachycordyle, and Thieliana, referred here to the subfamily Cordylophorinae, are presented.
\end{abstract}

Key words: freshwater and brackish Cnidaria, morphology, life history, nematocysts, karyotypes.

\section{INTRODUCTION}

The genus Pachycordyle and its type species, $P$. napolitana, were described at the end of the 19 th century (Weismann, 1883). However, the primary interest of August Weismann, a well-known German professor of zoology at the University of Freiburg and famous evolutionist, was research on the origin and maturation of germ cells in various hydroid and siphonophore species from the Bay of Naples. Unfortunately, his description of P. napolitana was

\footnotetext{
*Received February 28, 1999. Accepted .
}

incomplete because he gave neither a full diagnosis nor full illustrations of colonies, hydranths, or gonophores. The single illustration that he provided portrays a longitudinal section of a fragment of a pedicel, the gastroderm of which contained developing spermatoblasts (no female gonophores were illustrated). Major features used by Weismann as a basis for the establishment of a new genus, and for the new species $P$. napolitana, were the sparse branching of the colonies, "one whorl" of tentacles at the base of the hydranth hypostome, and attached gonophores that developed into medusoid-like nodules on the stem or branches. These attributes are of 
limited use in distinguishing $P$. napolitana from related species. Much attention was paid by Weismann to the layer in which germ cells developed. He assumed that germ cells had an ectodermal origin whether they matured in the endoderm (Pachycordyle) or in the ectoderm (Cordylophora). Much more important, in our estimation, is the formation and development of the gonophores. Unlike in Pachycordyle, those of Cordylophora do not form medusoid nodule but are transformed into sporosacs.

Hargitt (1904) described colonies of another hydroid of this genus from the Bay of Naples, with female gonophores, which he named $P$. weismanni. Medusoids of this hydrozoan developed the rudiments of a velum, marginal tentacles, and a ring canal. Hargitt found no radial canals and no mouth on the manubrium of the medusoids. According to the terminology of Kuhn (1913), such a gonophore should be termed a "eumedusoid". Hargitt observed that the medusoid of $P$. weismanni was liberated as an ephemeral, free-living (no more than 1-2 hours), abortive medusa. Its manubrium bore numerous eggs, which were shed into the water shortly after release of the medusa.

Hargitt (1904: 555, 556) believed that germ cells were formed in the ectoderm and he provided a relatively complete diagnosis of the hydroid that he named in honour of Weismann. The same year, Mayer (1904) described Parvanemus degeneratus from the Bahamas, later assigned (Mayer, 1910) to Pachycordyle as P. degeneratus. An additional nominal species, $P$. annulata, was described from the Mediterranean by Motz-Kossowska (1905). Like $P$. weismanni, it has been included in the synonymy of P. napolitana by most researchers. Parvanemus was included, with some doubt, in the synonymy of Pachycordyle by Calder (1988).

Notwithstanding the rather distinctive characteristics of Pachycordyle, many specialists have regarded it as a synonym of Cordylophora (Picard, 1958; Morri, 1980, 1981). The diagnosis of the latter was broadened (Morri, 1980) to include species in which gonophores varied in degree of reduction from sporosacs to free medusae.

Stechow $(1919,1921)$ twice repeated a proposal of the genus name Clavopsella for C. weismanni and C. annulata. The principal attributes of the genus, according to Stechow, were: (1) tentacles of polyps restricted to the apical part of the hydranth, and (2) gonophores medusoid, lacking radial canals and a mouth on manubrium but with a ring canal and rudi- ments of a velum. Pachycordyle weismanni was designated the type species of Clavopsella. Stechow did not retain Pachycordyle and ignored P. napolitana, the type species of Pachycordyle.

Thiel (1962) described as Clavopsella quadranularia a hydroid from the Kiel Canal. Millard (1975) concluded that the species was identical with $R h i$ zorhagium navis, described by her earlier (Millard, 1959) from South Africa. Also part of this group, in our opinion, is Cordylophora inkermanica (Marfenin, 1983) from the Black Sea. It seems likely that all are conspecific. Thiel (1962) was the first to describe in detail the very peculiar life cycle in this species. He established a new family, Clavopsellidae, for it and for the related genus Balella.

There is some uncertainty about the taxonomic affinities of these hydrozoans. Weismann (1883) compared Pachycordyle with Corydendrium and Cordylophora (family Clavidae). Stechow (1923) included Clavopsella in the same family, although he earlier (Stechow, 1919) had assigned it to the Bougainvilliidae. Millard (1975), Calder (1988), and others included Pachycordyle in the Bougainvilliidae (but Cordylophora in the Clavidae). Thiel (1962) referred the genus to the family Clavopsellidae. Our arguments in favour of assigning Pachycordyle to the family Clavidae are presented at the end of this paper.

\section{MATERIALS AND METHODS}

The benthic biota of Lake Biwa (central Japan) was sampled as part of biodiversity studies during joint Russian and Japanese expeditions in 1996-97. Small epibiotic colonies of hydroids (Fig. 1A) were found by Dr. O. A. Timoshkin along the western shore of the southern part of the lake in front of the site of the Center for Ecological Research, Kyoto University (the Center has since moved). The samples were from a depth of 0.5-2.0 m. Such polyps are previously unreported as part of the fauna of the lake. The morphology and histology of the hydroids were studied in detail based on live and preserved material. Photographs (black-and-white and colour) were also taken of live specimens. Nematocyst morphology and structure of medusoids (both external and histological) were examined and photographed using a stereoscope (MBI) and a compound microscope (Amplival, with phase contrast optics and an automatic camera). Chromosome preparations were made using an air-drying technique (Ovanesyan and 

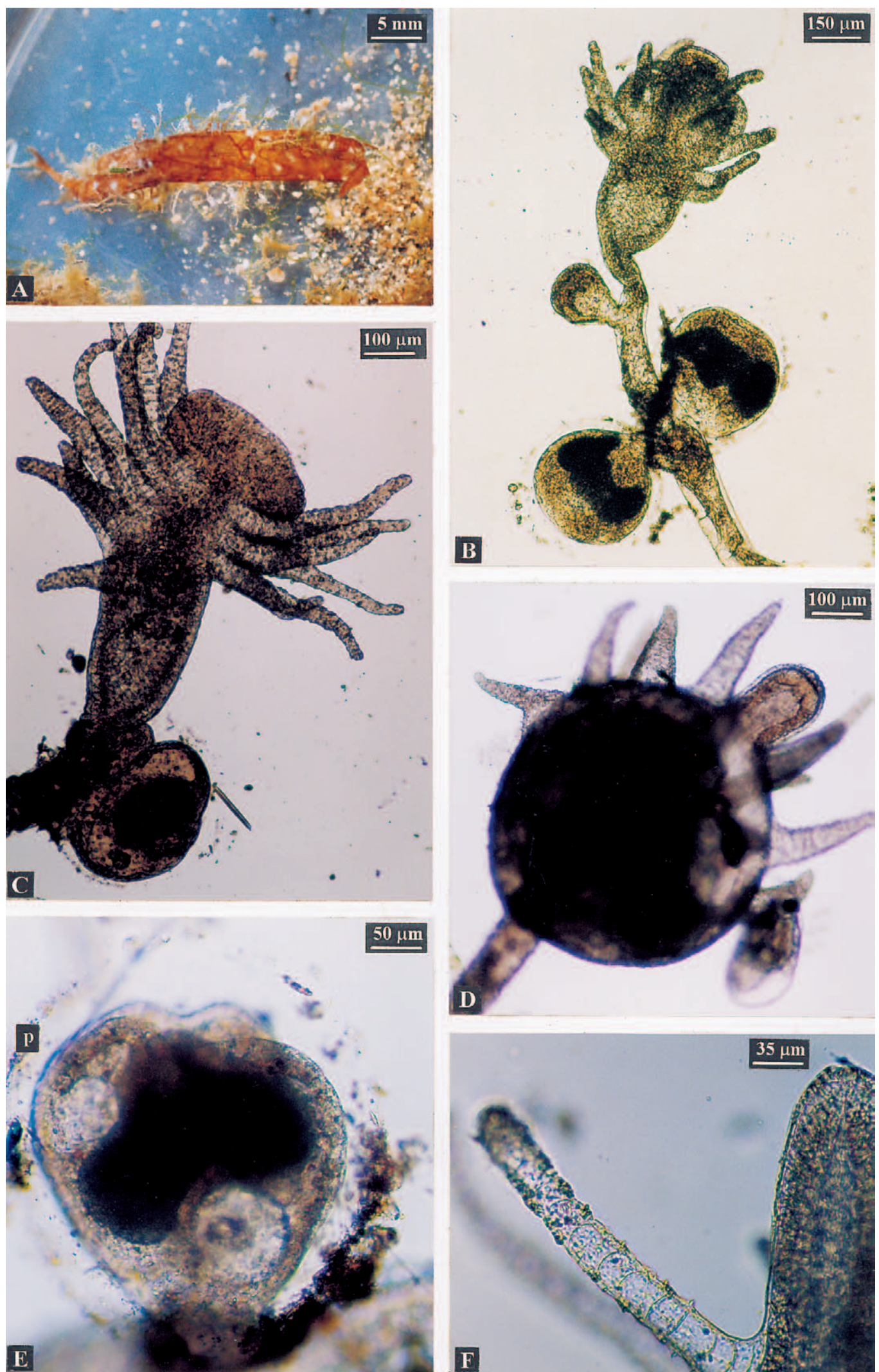

FIG. 1. - Type colony of Pachycordyle kubotai sp.n. from Lake Biwa (photographs by O. Timoshkin); A, fragment of colony collected 15.07.1997 on western coast of south Lake Biwa; B, stem with terminal hydranth and 3 gonophore buds; C, contracted hydranth with imprecise whorls of tentacles and opened mouth of hypostome; D, head of a satiated hydranth with contracted tentacles; E. Eumedusoid, p - perisarc; F, solid polyp tentacle showing its vertical row of gastrodermal cells. 
Kuznetsova, 1995). Specimens were incubated in $0.4 \%$ sodium citrate and fixed in an ethanol-acetic acid mixture (3:1). Specimens were then placed individually on a slide and macerated in $70 \%$ acetic acid. Thereafter, slides were air-dried and stained by the conventional Giemsa technique.

Morphological comparison of the specimens with accounts of related species indicated that these hydroids constitute a new species. We name it Pachycordyle kubotai, in honour of the hydrozoan specialist Dr. Shin Kubota (Kyoto University), who carried out investigations on freshwater Hydrozoa of Japan for his undergraduate thesis.

\section{RESULTS}

\section{Pachycordyle kubotai sp. n.}

Holotype: Colony composed of a hydrorhiza growing on a small piece of wood; western coast of southern Lake Biwa (central Japan), in front of the then site of the Center for Ecological Research, Kyoto University; depth 0.1-1.0 m, 5-11.07.1997; 24.725.1 C; ZIN RAS (Zoological Institute, Russian Academy of Sciences) $n^{\circ} 10302 / 1$. A fragment is also deposited in the Lake Biwa Museum (slide in Canada Balsam)

Paratypes: $\mathrm{n}^{\circ} 1$ : colony composed of small, unbranching or irregularly branching stems arising from stolonal hydrorhiza; collection as for holotype except depth ca. 1.0 m; 5-17.07.1997; ZIN RAS n ${ }^{\circ}$ $10303 / 2 . \mathrm{n}^{\mathrm{O}} 2$ : small, sterile colony composed of unbranching stems, collection data as for Paratype $\mathrm{n}^{\circ} 1$; ZIN RAS n ${ }^{\circ} 10304 / 3 . \mathrm{n}^{\circ}$ 3: unbranched, sterile stems rising from hydrorhiza covering a fragment of a plant; locale as above; depth unrecorded; ZIN RAS $n^{\circ}$ $10305 / 4$.

Other Material: In ZIN RAS collections, a fragment of a colony with hydranths tangled in algal thalli, in poor condition, hydranths small and contracted. Colony fragments from holding tank $n^{\circ} 4$ of aquarium of Lake Biwa Museum; 26.03.1988; coll. Dr. Mark J. Grygier, Mr. Hiromitsu Akiyama, and Dr. Yasushi Kusuoka. The colony from this tank is currently alive in the aquarium of Boris Anokhin (ZIN RAS, St. Petersburg).

Description of holotype: Colony composed of many small stems (not more than $2.2 \mathrm{~cm}$ each) rising vertically from filiform hydrorhiza. Each stem with a terminal hydranth having a gonophore-budding zone beneath hydranth base. Colonies typically with one mature gonophore (rarely two) and several (not more than 4-5) immature ones at different stages of development. Hydrorhiza and stems covered with rather dense, light brown perisarc annulated along almost entire length, reaching base of hydranth where annulation is particularly distinct. Hydranths of living colonies elongate-fusiform, with hypostome elongate-conic (when polyp is hungry) or nearly spherical (when polyp is satiated) (Fig. 1D). Mouth in form of an opening into canal of hypostome, open or turned inside out (if polyp is ready to swallow food) (Fig.
1C). Tentacles solid, with a central core of gastrodermal cells lying one under the other (Fig. 1F). Tentacles located on upper half of hydranth around and slightly below hypostome, with 3-4 indistinct whorls, appearing randomly arranged ("Cordylophora-like") in hungry polyps (Fig. 1C, D). Tentacles varying in number from 11-14 (rarely to 17). Erect tentacles of hungry polyp fairly long, extending beyond hypostome. Tentacles of satiated polyps contracted, about 1/4 length of those above, whorls appearing coalesced and merged almost into one ring.

Gonophores budding on stem below hydranth (Fig. 1B, E). Oocytes developing in ectoderm (Fig. 2), rather large early in development of medusoid bud. Each gonophore with two oocytes, with a large gastric cavity and four radial canals. Gastroderm of gastric cavity and canals with cubical cells. Lower part of gonophore with well developed mesoglea. Ring canal, velum, and marginal tentacles lacking. Gonophore eumedusoid, surrounded by transparent, spongy, thin, mucous-like perisarc (Figs. 1E, 2C, 6A). The maturity of oocytes (July - see p. 000) indicated that their release was imminent and that the medusoids were nearly ready for release, assuming that they are liberated from the hydroid.

Measurements (in $\mathrm{mm}$ ). Height of the stem 10.17-20.21; diameter of perisarc stem tube $0.052-$ 0.060; height of polyp head 0.65-0.78; maximal width of polyp head 0.42 ; length of polyp hypostome 0.09-0.13; width of polyp hypostome 0.07; length of tentacles 0.13-0.20; height of developed gonophore with pedicel 0.39 ; length of gonophore without pedicel $0.32-0.33$; diameter of developed gonophore 0.29 .

Nematocysts (examined in live specimens, in $\mathrm{mkm}$ ): Microbasic euryteles 6.5-7.0 x 3.0-3.5 and desmonemes - 4.5 x 3.0-3.2 (Fig. 3).

Karyotype: $2 \mathrm{n}=30$. Consists of 30 isomorphic chromosomes forming a gradually decreasing size row. Each chromosome of the fourth pair carries a distinct negatively heteropycnotic region (Fig. 4).

Description of paratypes: (Nos. 1, 2, 3). Paratype colonies differing little from holotype morphologically except for structure of colonies proper (in paratype $n^{\circ} 1$, stems can form branches of the first and second orders). Hydranths of paratype colony $n^{\circ}$ 3 evidently satiated at moment of fixation because their hypostomes almost indistinct, and the heads of 

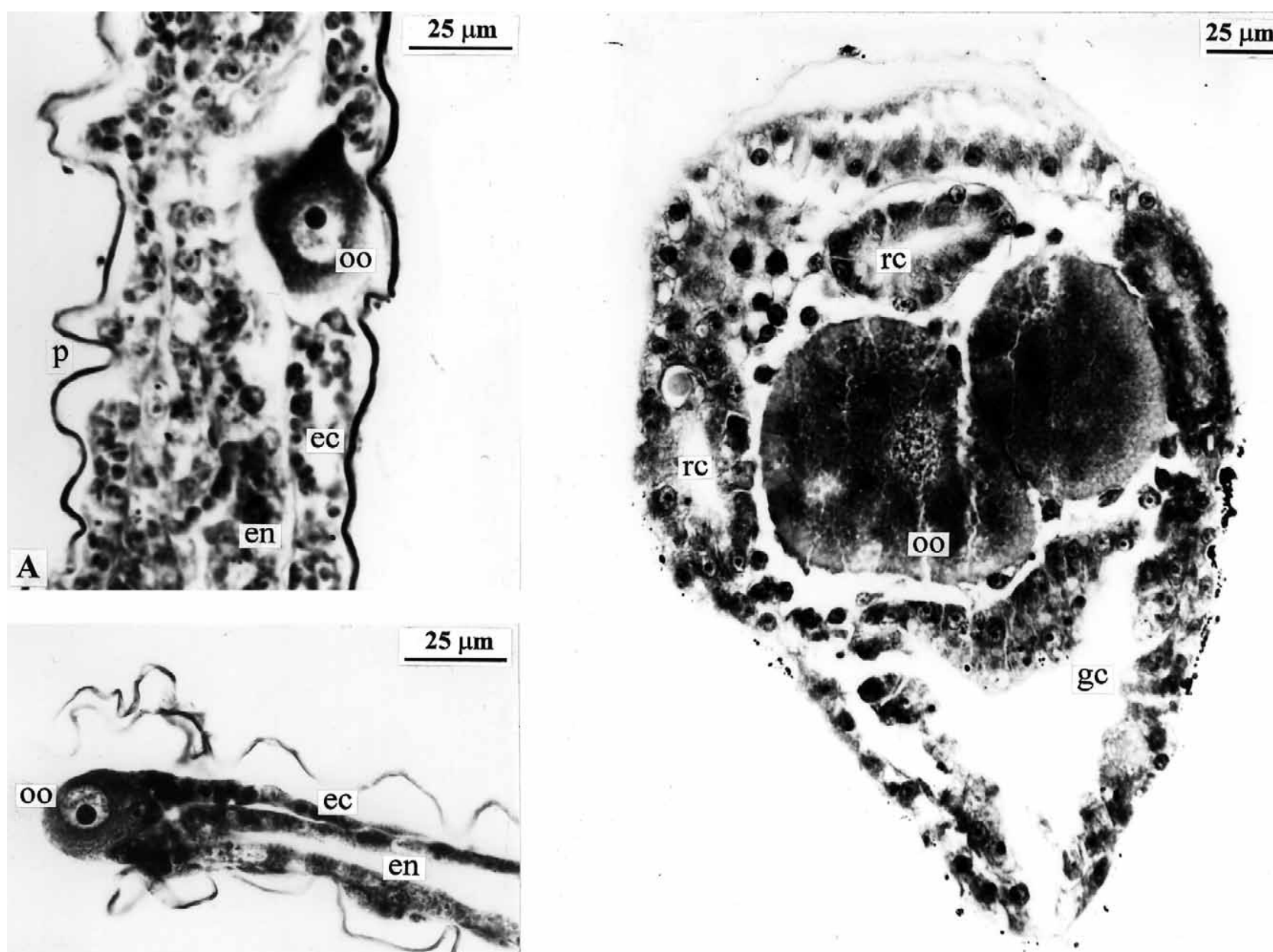

B

\section{C}

FIG. 2. - Pachycordyle kubotai, stages of gonophore formation. A, zone of stem below hydranth with developing oocytes; B, early stage of gonophore bud formation; C, mature eumedusoid. ec - ectoderm; en - entoderm; rc - radial canals; gc - gastral cavity; oo - oocyte
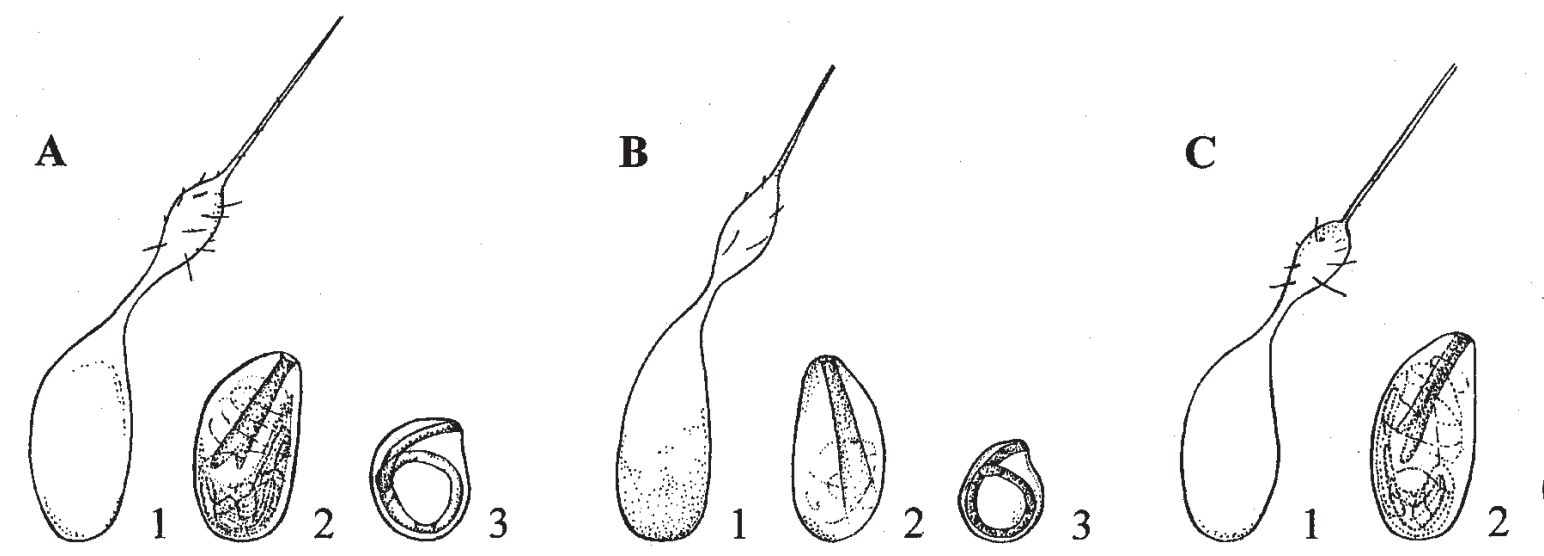

$3 \mu \mathbf{m}$

FIG. 3. - Nematocysts of three representatives of the subfamily Cordylophorinae. A, Pachycordyle kubotai; B, Thieliana inkermanica; C, Cordylophora sp. 1,2 - microbasic euryteles: discharged capsula (1) and undischarged capsula (2); 3 - undischarged desmoneme. 

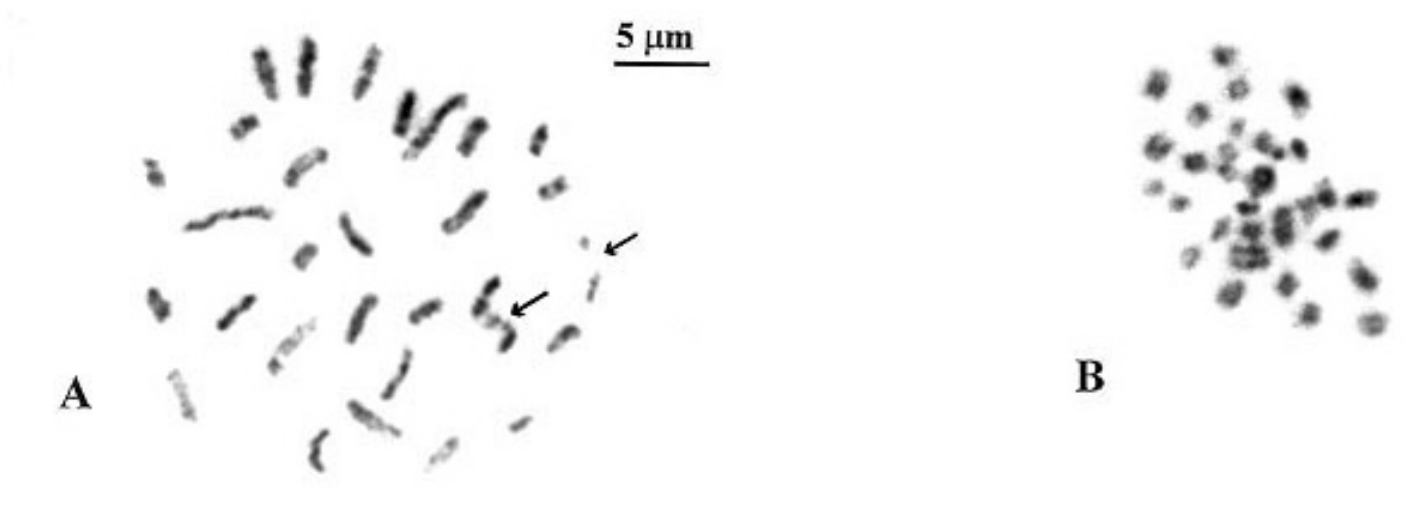

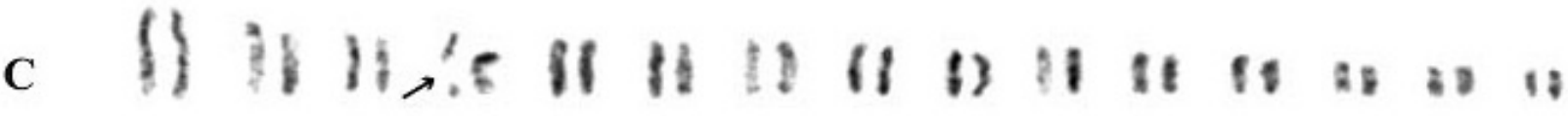

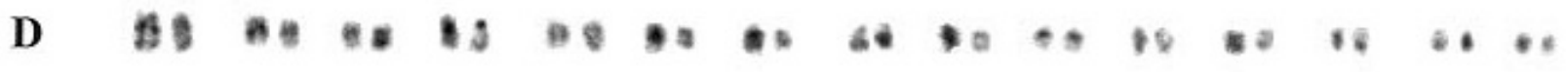

FIG. 4. - Mitotic chromosomes of representatives of two genera of Cordylophorinae. A, Pachycordyle kubotai, mitotic metaphase, $2 \mathrm{n}=$ 30; B, Cordylophora sp., mitotic metaphase, $2 \mathrm{n}=30$; C, karyogram of Pachycordyle kubotai; D, karyogram of Cordylophora sp. The negatively heteropycnotic regions on the fourth chromosome pair of Pachycordyle kubotai are visible (arrows).

polyps nearly round; their length and width nearly the same - about $0.65 \mathrm{~mm}$.

\section{DISCUSSION}

Pachycordyle kubotai is related to and believed congeneric with $P$. napolitana (and its synonyms $P$. weismanni and $P$. annulata). Attributes of the species that conform with the diagnosis of the genus include the following: (1) tentacles of hydranth restricted to distal end, and (2) gonophores eumedusoid. We do not share the opinion of some authors that the degree of medusa development or reduction has no taxonomic significance (Petersen, 1990, as applied to Capitata; Boero, Bouillon, and Piraino, 1996, as applied mainly to Campanulariidae; Boero, Bouillon, and Piraino, 1998, as applied to Hydractiniidae). Our position, outlined in discussions of Corymorphidae (Stepanjants and Svoboda, 1999) is that gonophore development in combination with other attributes (e.g., gonophore position, blastostyle construction, etc.) may be of taxonomic value.

Pachycordyle kubotai possesses some peculiarities distinguishing it from $P$. napolitana:

1. The perisarc in colonies of $P$. napolitana is irregularly wrinkled, whereas the perisarc of $P . k u b$ otai is uniformly wrinkled.
2. The number of tentacles on polyps of $P$. napolitana varies from 8-20, while those of P. kubotai are no less 11 and no more than 17.

3. The female gonophore is elongate-oval in $P$. napolitana and almost rounded in P. kubotai.

4. There are 1-4 oocytes in developing female gonophores of P. kubotai; this number is larger in $P$. napolitana.

5. Female gonophores of $P$. napolitana have a ring canal and a velum, but no radial canals; female gonophores of $P$. kubotai have 4 radial canals and no ring canal and velum.

6. Both species have the same two types of nematocysts: desmonemes and microbasic euryteles, but the capsules of the latter are slightly larger in P. napolitana $(10 \times 4.5 \mathrm{mkm})$ than in P. kubotai $(7 \mathrm{x}$ $3.5 \mathrm{mkm})$.

7. Pachycordyle napolitana inhabits marine basins or bodies of water with reduced salinity (more often about 20\%: Morri, 1980), but P. kubotai is found in freshwater only.

Colonies similar in form to this hydroid were found earlier in brackish waters of Japan and described as new species: Cordylophora japonica by Ito (1951) and C. mashikoi by Ito (1952). Ito provided descriptions and differential diagnoses of these hydroids, comparing his new species mainly with Cordylophora lacustris, but distinctions between these species and $C$. lacustris were not 
clearly presented by the author. Cordylophora japonica is clearly not referable to Pachycordyle because its hydranths have tentacles that are irregularly distributed over its surface and its gonophores are sporosacs rather than medusoids. However, $C$. mashikoi may be referable to Pachycordyle because its tentacles are located at the distal end of the hydranth just below the hypostome. Female medusoids are unknown for the latter species, and the pattern of male gonophores is poorly described. Nevertheless, C. mashikoi differs from P. kubotai by its irregular branching of colonies and larger number of gonophore buds (each gonophore is approximately $0.3 \mathrm{~mm}$ long), distributed in a budding zone on the ramuli (up to 12 buds on each ramulus).

Negoro (1982) reported the discovery of medusae in the southern part of Lake Biwa, near the Seta River entrance, during October 1977. The medusae were very small (about $600 \mathrm{mkm}$ in diameter) with a manubrium, radial canals, and rudiments of marginal tentacles (judging from illustrations in his atlas). As the illustrated medusa does not resemble the well-known Craspedacusta, this medusa might be a species of Pachycordyle. However, verification is needed to be sure of the identity. Discovery of the medusa of P. kubotai would contribute to knowledge of the life cycle of the species and resolve questions about the family affinities of the taxon.

Stechow (1919) established Clavopsella as a new genus, with Pachycordyle weismanni as its type species. He did not accept Pachycordyle as valid, believing that $P$. napolitana should be referred to Rhizorhagium. We do not accept Stechow's view because Rhizorhagium (type species $R$. roseum) is a typical bougainvilliid with one whorl of filiform tentacles, a pseudohydrotheca, and gonophores as sporosacs. We consider Clavopsella a junior synonym of Pachycordyle and retain the older name, which has priority. The spelling $P$. neapolitana used by some authors for the type species is an incorrect subsequent spelling (Calder, 1988).

\section{Genus Pachycordyle Weismann, 1883}

Type species: Pachycordyle napolitana Weismann, 1883 , by monotypy.

Diagnosis: Clavid colonies characterized by small unbranched or little-branched stems arising from a filiform hydrorhiza. Coenosarc of hydroid colony covered by light-yellow or brown, smooth or partly or fully wrinkled perisarc. Stem and branches terminating in hydranths. Tentacles of hydranths filiform, solid, arranged in several (3-4) whorls on upper half of hydranth around hypostome. Stem or branches with a gonophore budding zone immediately below base of hydranth. Mature gonophore eumedusoid, with radial or ring canals present; velum and marginal tentacles more or less developed. Medusa, if liberated, short-lived and living in plankton not more than several hours. Oocytes from 1-12 in female eumedusoids.

Representatives of the genus inhabit brackish and freshwater environments.

\section{Key to known species of Pachycordyle}

1(2). Gonophore buds forming on ramuli, several on each ramulus ....................P. mashikoi

2(1). Gonophore buds not on ramuli, arising one by one on stem or branch.

3(4). Ring canal and velum present; radial canals lacking in eumedusoid; up to 10 or more oocytes................P. napolitana 4(3). Radial canals present; velum and ring canal lacking; not more than 4 oocytes ........P. kubotai

After Stechow (1919) proposed Clavopsella, two species were added to the genus: C. navis (Millard, 1959) and $C$. quadranularia Thiel,1962. The latter was subsequently referred to the former as a junior synonym (Millard, 1975). A peculiarity in their life cycles is a common attribute of both of these hydroids: developing oocytes are concentrated in the apical part of the medusoid and transform there into planulae before being released into the water by twisting themselves out of the gonophore. In this regard, $C$. navis differs markedly from $P$. weisman$n i$, for which Stechow erected Clavopsella. As already noted, Clavopsella is a junior synonym of Pachycordyle. Clavopsella navis and C. quadranularia, with cryptomedusoid gonophores and different life cycles, do not belong in this genus. We establish a new genus, Thieliana, after $\mathrm{H}$. Thiel, who provided a comprehensive description of the peculiarities of the representatives of this genus in his account of $C$. quadranularia.

No colonies of Thieliana quadranularia or $T$. navis were available to us, and it was thus impossible to determine whether the nominal species are conspecific, as Millard (1975) contended.

Besides the above-mentioned two species of Clavopsella, we also assign to Thieliana a species 
from the Black Sea described by N. N. Marfenin (1983) as Cordylophora inkermanica. The differential diagnosis of $C$. inkermanica did not mention Clavopsella navis and $C$. quadranularia, despite a certain morphological similarity among all three species. Their similarity lies in the same kind of stem branching; a similar perisarc pattern, generally smooth but annulated in some parts; the structure of the hydranths and medusoids, and the size of the latter; the sizes of the planulae emerging from the gonophores; and the sizes of the nematocyst capsules (Figs. 3B, 5D, 6B).
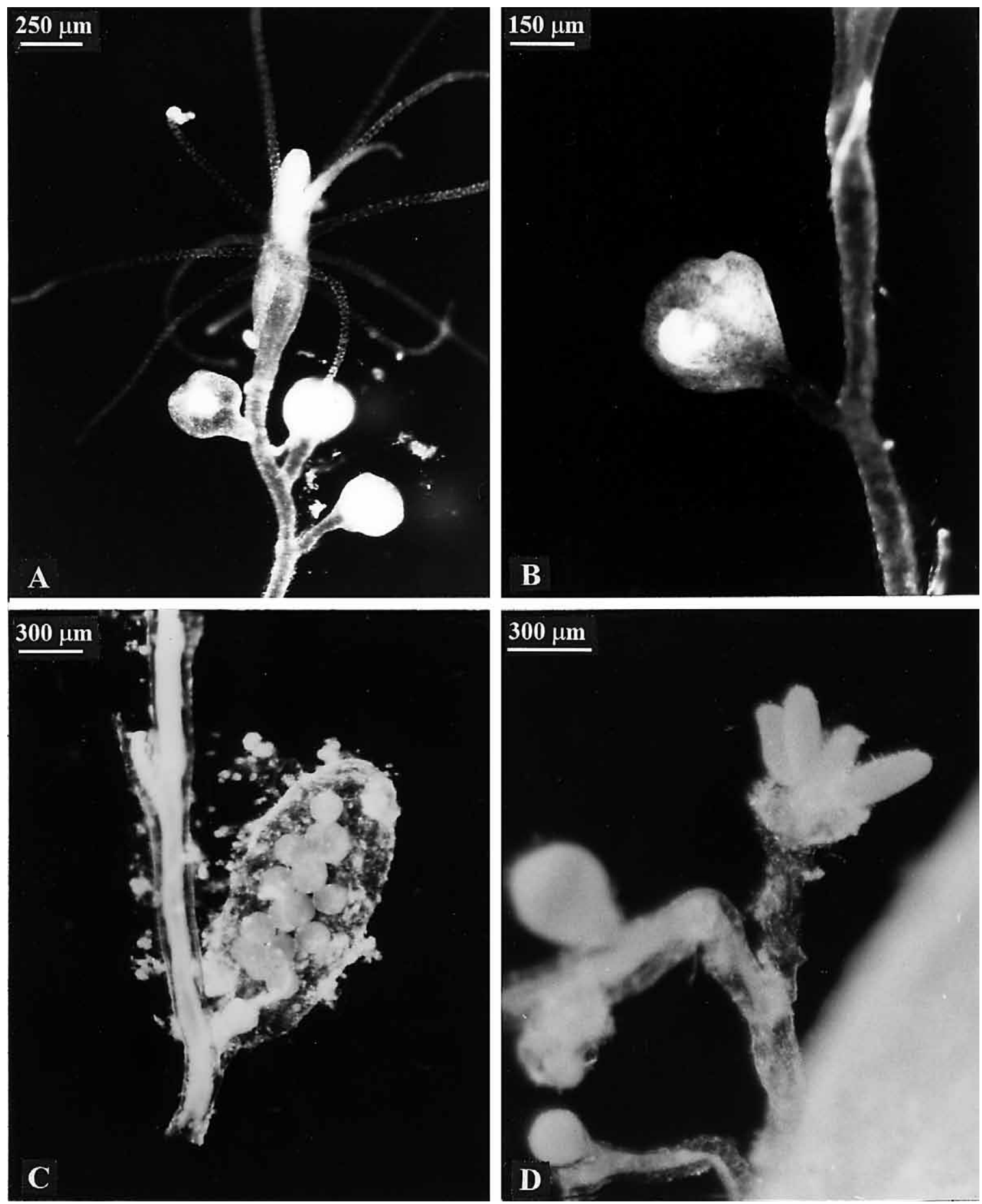

FIG. 5. - Representatives of the subfamily Cordylophorinae (photographs by B. Anokhin). A, fragment of living colony of Pachycordyle kubotai from aquarium of Zoological Institute RAS, St. Petersburg: hydranth with gonophores (A) and female eumedusoid (B); C, gonophore of living colony of Cordylophora sp. From aquarium of Zoological Institute RAS, St. Petersburg; D, fragment of colony of Thieliana inkermanica (Marfenin) with gonophores and mature planulae (collection of Zoological Institute RAS). 


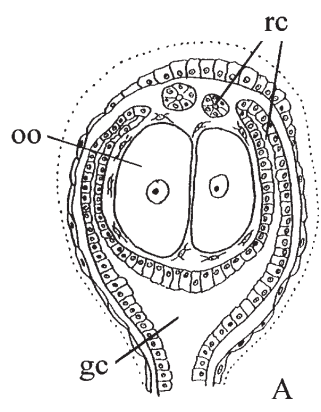

A
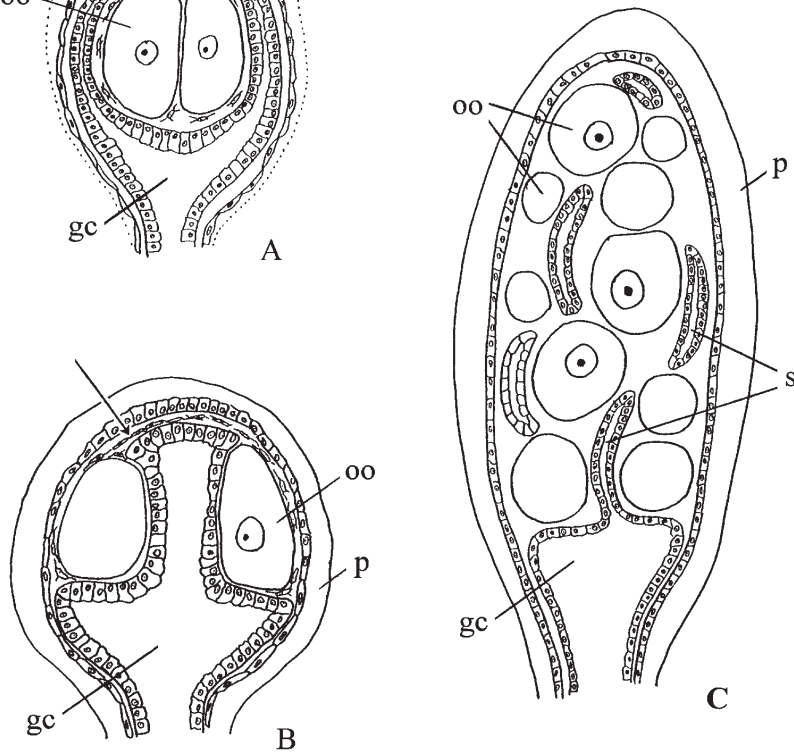

FIG. 6. - Diagrams of female gonophore morphology of representatives of Cordylophorinae. A, eumedusoid of Pachycordyle kubotai; $\mathrm{B}$, cryptomedusoid of Thieliana inkermanica; C, sporosac of Cordylophora sp. oo - oocytes; gc - gastral cavity; s - spadix; p perisarc; rc - radial canals; subumbrellar cavity rudiment (arrow).

\section{Genus Thieliana gen.n.}

Type species: Clavopsella quadranularia Thiel, 1962, by original designation herein.

Diagnosis: Colonies in form of unbranching or branching stems rising from creeping hydrorhiza. Coenosarc of stem and branches covered by smooth or segmented perisarc. Stems and branches terminating in hydranths. Hydranth head ending in hypostome with two whorls of filiform tentacles around its base. Lower part of polyp head lacking tentacles. Budding zone of gonophores on stem or branch below hydranth base. Solitary gonophores on pedicels. Gonophores as cryptomedusoids lacking radial and ring canals, velum, and tentacle rudiments; subumbrellar cavity well-defined (Fig. 6B). Formation of female gonophores very peculiar: oocytes become concentrated in apical part of gonophore in one or two rows, grow into planulae within gonophore, and then leave it (Fig. 5D).

The representatives of this genus are euryhaline marine organisms, which can survive at salinities from $7 \%$ up to $35 \%$.

Representatives of Pachycordyle have been assigned by different taxonomists to either Clavidae
(Stechow, 1923; Morri, 1980), Bougainvilliidae (Millard, 1975; Bouillon, 1985; Calder, 1988), or Clavopsellidae (Thiel, 1962). The last assignment is untenable since Clavopsella is considered by us to be a synonym of Pachycordyle.

What are the diagnostic characters of the Clavidae and Bougainvilliidae, and where might Pachycordyle best be assigned?

The family Clavidae is characterized by solitary or colonial hydroids, the coenosarc of which is covered by perisarc while the hydranths are always devoid of an exoskeleton (i.e., no hydrotheca or pseudohydrotheca is present). Hydranths are fusiform with an elongate-conic hypostome. Tentacles are solid and filiform and either randomly arranged over the hydranth or in indistinct whorls. The tentacle arrangement is best observed in living colonies. Those of a living, hungry polyp appear to be scattered, although they often gather in indistinct whorls after fixation. This sort of tentacle arrangement is seen in Turritopsis, Rhizogeton, and Tubiclava, and also in Pachycordyle and Thieliana, but to a greater extent. Gonothecae occur on stems or branches, on the body of the hydranth, or rarely on the hydrorhiza. Gonophore development varies from free medusae (Turritopsis) to styloid gonophores (Clava). Both facultative (Pachycordyle) and complete (Turritopsis, Oceania) detachment of free medusae are known. The characteristic feature of these medusae is the presence of vacuolated cells in the apical part of the stomach gastroderm. Other features of the medusa are numerous marginal tentacles and a mouth with four lips.

Members of the Bougainvilliidae are exclusively colonial hydroids. Their coenosarc is covered by perisarc generally extending to the hydranth, or even covering it as a pseudohydrotheca. Tentacles are solid, filiform, and commonly arranged in a single whorl around the hydranth below the hypostome. The arrangement is orderly in both living and preserved specimens. Free medusae are characterized by the presence of oral tentacles and groups of marginal tentacles. Gonophores develop on the hydrorhiza, stem, and branches (sometimes on special blastostyles), and vary in development from medusae to styloid gonophores.

Nematocysts are of two categories: microbasic euryteles and desmonemes.

Basaed on the attributes listed above for the two families, we assign Pachycordyle and Thieliana to the Clavidae.

The family Clavidae includes about 10 genera (Bouillon, 1985), some of which have well devel- 
oped free medusae (Oceania, Turritopsis). Representatives of other genera have gonophores of varying degrees of degeneration. Some have solitary hydranths arising from the hydrorhiza (Clava, Tubiclava, Rhizogeton), and Hataia has solitary polyps without a hydrorhiza. Merona is unique in the group in having nematothecae. Corydendrium differs in having branched colonies in which the branches fuse with the stem, and in having gonophores arising under the perisarcal tubes of the branches. Cordylophora appears closest to Pachycordyle and Thieliana.

How are Cordylophora, Pachycordyle, and Thieliana alike, and how do they differ? First, they are alike in:

1. colony form, with stems arising from a filiform hydrorhiza and branches irregular when present;

2. skeletal form, with perisarc over coenosarc of stem and branches being smooth or more or less wrinkled;

3. growth form (monopodial with terminal hydranths);

4. hydranth shape, being elongate-conic with a conical hypostome (hydranths of satiated hydroids being almost globe-shaped);

5. tentacle arrangement, with scattered filiform tentacles over hydranth;

6. arrangement of gonophores, arising from stems and branches below hydranth bases and not from hydrorhiza;

7. gonophore type, with reduced medusoids or fixed sporosacs rather than free medusae.

These genera differ in the following characters:

1. colony branching pattern and overall height, with Cordylophora having stronger, more extensively branched colonies that may reach $10 \mathrm{~cm}$ high (we consider $C$. caspia and $C$. lacustris to be distinct and valid species); colonies of Pachycordyle and Thieliana are smaller $(2-3 \mathrm{~cm})$ and less branched;

2. tentacle arrangement, with those of Cordylophora being scattered over the hydranth and those of Pachycordyle and Thieliana being concentrated in several indistinct whorls at the distal end of the hydranth;

3. gonophore morphology, with fixed sporosacs and many oocytes in Cordylophora and a different gonophore type in the other two genera (Fig. 6). As noted above, data from Weismann (1883: 30) indicate that sporosac development in Cordylophora bypasses the medusoid nodule stage.
We investigated the nematocysts and karyotype of young Cordylophora from the Gulf of Finland. Nematocysts of representatives of all three genera, and karyotypes of Pachycordyle kubotai and Cordylophora sp., are shown in Fig. 3.

The clear similarities listed above indicate that Cordylophora, Pachycordyle, and Thieliana are closely related, and we combine the three in the clavid subfamily Cordylophorinae von Lendenfeld, 1885.

We here redefine the subfamily as follows:

Diagnosis. Colonies with creeping hydrorhiza and with unbranched or irregularly branched stems; branches many or few; colony height from $1-2 \mathrm{~cm}$ to $>10 \mathrm{~cm}$; coenosarc of stems and branches covered by smooth or wrinkled perisarc; pseudohydrotheca lacking; growth monopodial with terminal hydranths. Hydranths bearing solid filiform tentacles; tentacles scattered or in indistinct whorls. Gonophores arising from a budding zone beneath hydranth base, solitary on pedicels or a few on a ramulus. Gonophore development varying from styloid, cryptomedusoid to eumedusoid, with radial canals, ring canal, reduced marginal tentacles, velum, gastric cavity, and subumbrellar cavity sometimes present. Eumedusoids, when present, may become free and survive for several hours in the plankton. No fully developed free medusae known.

Other groups of Clavidae have representatives with one or more of the following characteristics: (1) free medusae; (2) spreading colonies; (3) solitary polyps; (4) nematothecae; (5) gonophores inside perisarcal tubes of branches.

\section{Key to Cordylophorinae}

1(2). Tentacles scattered over surface of hydranth; gonophores styloid........Cordylophora

2(1). Tentacles in several indistinct whorls on upper half of hydranth; medusoids not styloid.

3(4). Tentacles in 3-4 whorls; gonophores eumedusoid, no planulae developing inside gonophore Pachycordyle

4(3). Tentacles in 2 whorls; gonophores cryptomedusoid, planulae developing inside apical part of gonophore Thieliana

\section{Ecology}

Representatives of the Cordylophorinae are mostly eurybionts. Representatives of Cordylophora 
are widespread in marine, brackish, and even fresh waters. In terms of geographic range, they have been reported from the North Atlantic; the Mediterranean, Black, Caspian, and Azov seas; continental waters of Europe; and brackish and fresh waters of Japan, Australia, and New Zealand (Bouillon et al., 1995; Schuchert, 1996). They have been found at salinities from $0-35 \%$ (optimal 5-15\%o), and at temperatures from $2-30^{\circ} \mathrm{C}$ (optimal $6^{\circ} \mathrm{C}$ ) (Kinne, 1963, 1964; Morri,1980; Calder,1990).

Cordylophora occurs on algal thalli, mollusc shells, and pieces of wood.

Pachycordyle has been found in shallow waters of the Bay of Naples and other parts of the Mediterranean (Adriatic and Aegean Seas); the western Atlantic (Wedler and Larson, 1986); Bermuda (Calder, 1988); possibly Nassau Harbour, Bahamas, as abortive medusoids (Mayer, 1910); and lakes of Japan (including the entirely freshwater Lake Biwa as well as the brackish Ono River - Lake Kahokugata, connected to the Sea of Japan). They occur mainly at salinities of 0-20\%o, but in Bermuda, near Harrington Sound, Calder (1988) found a $2 \mathrm{~mm}$ high colony at $2 \mathrm{~m}$ depth in water with a salinity $35-36 \%$. Their temperature range is the same as for Cordylophora. Substrates include algae, Zostera, mollusc shells, crustacean carapaces, and pieces of wood.

Hydroids of Thieliana have been found in Table Bay, South Africa, on hulls of ships; in the Kiel Canal; and in the Black Sea (Inkerman and Jarylgachsky Bays) at depths from $20 \mathrm{~cm}$ to $6 \mathrm{~m}$. The reported salinity range is $7-35 \%$, and the temperature range, $2-20^{\circ} \mathrm{C}$. Substrates include mollusc shells, stones, plant debris, pieces of wood, and hulls of ships.

\section{CONCLUSIONS}

1. Detailed investigations were made on a new species of hydroid, Pachycordyle kubotai, from Lake Biwa, Japan.

2. Careful consideration of its characters, and those of related species, indicates that it belongs to the genus Pachycordyle. A new diagnosis of this genus and a key to the species included in it are provided.

3. Morphological studies show that the nominal genus Clavopsella is a junior synonym of Pachycordyle, while some of its included species are generically distinct. The new genus Thieliana is erected for these latter species.
4. Contrary to a number of recent publications, Pachycordyle and Thieliana are assigned to the family Clavidae rather than the Bougainvilliidae.

5. Pachycordyle and Thieliana are shown to be most closely related to Cordylophora within the Clavidae. The three genera are included in the subfamily Cordylophorinae. An identification key is provided to these genera.

\section{ACKNOWLEDGEMENTS}

The authors are thankful to the Organizing Committee of the IV International Conference of Hydrozoan Biology, held at Bodega Bay, and the Editoral Board of these Proceedings, namely, Professors J.M. Gili and F. Boero and Dr. Claudia Mills, for deciding to publish this paper in the Proceedings of the Conference, notwithstanding that the authors could not participate in it. Investigations were partly supported by a grant, "A New Programme for Creative Basic Research, MESSC-Japan on an Integrative Study on Biodiversity Conservation under Global Change and Bioinventory Management System", awarded to the Center for Ecological Research of Kyoto University by the Japan Ministry of Education, Science, Sports and Culture, and by Grants $n^{\circ}$ 97-04-96237-Baikal and $n^{\circ}$ 97-04-50100 of the Russian Foundation for Basic Research, Russian Programme "Biodiversity". The authors are also thankful to Professor Dr. E. Wada for supporting the cost of including the coloured plate, and to Drs. Mark J. Grygier and Yasushi Kusuoka and Mr. Hiromitsu Akiyama for sending supplementary material of $P$. kubotai from the Lake Biwa Museum to St. Petersburg in a state suitable for establishing a colony of the species alive at the Zoological Institute RAS. We offer our thanks to E. Timoshkina for preparing the first translated English draft of this paper, and we are happy to thank Drs. Dale Calder and Mark J. Grygier for important comments on this article and correction of English.

\section{REFERENCES}

Boero, F., J. Bouillon and S. Piraino. - 1996. Classification and phylogeny in the Hydroidomedusae (Hydrozoa, Cnidaria). In: Piraino, S., Boero, F., Bouillon, J., Cornelius, P.F.C., and Gili, J.M. (eds.) Advances in Hydrozoan Biology. Sci. Mar., 60(1): 17-33.

Boero, F., J. Bouillon and S. Piraino. - 1998. Heterochrony, generic distinction and phylogeny in the family Hydractiniidae (Hydrozoa: Cnidaria). In: Den Hartog, J.C., Van Bruggen, A.C., Cornelius, P.F.S. and Van Ofwegen, L.P. (eds.), Com- 
memorative volume for the 80th birthday of Willem Vervoort in 1997. Zool. Verhandl., 323: 25-36.

Bouillon, J. - 1985. Essai de classification des HydropolypesHydromeduses (Hydrozoa-Cnidaria). Indo-Malayan Zool. 2, 1 : 29-243.

Bouillon, J., C. Massin and R. Kresevic. - 1995. Hydroidomedusae de l'Institut Royal des Sciences naturelles de Belgique. Docum. travial Inst. roy. Sci. nat. Belgique. 78: 1-106.

Calder, D.R. - 1988. Shallow-Water Hydroids of Bermuda. The Athecatae. Life Sci. Contr. ROM, 148: 1-108.

Calder, D.R. - 1990. Seasonal cycles of activity and inactivity in some hydroids from Virginia and South Carolina, U.S.A. Canadian. J. Zool., 68(3): 442-450.

Hargitt, C.W. - 1904. Notes on some hydromedusae from the Bay of Naples Mitteil. Zool. Stat. Neapel, 16(1,2): 553-585.

Ito, T. - 1951. A new Athecate Hydroid, Cordylophora japonica n. sp., from Japan. Mem. Ehime Univers., Sec.II(Science), 1, 2: 81-85.

Ito, T. - 1952. A new species of Athecate Hydroid Cordylophora from Japan Spec. Publ. Japan Sea Region. Fish. Res. Lab., Nanao: 55-57.

Khün, A. - 1913. Entwicklungsgeschichte und Verwandtschaftsbeziehungen der Hydrozoen, I. Teil. Die Hydroiden. Ergebn. Fortschr. Zool, 4, 1: 1-284.

Kinne, O. - 1963. The effects of temperature and salinity on marine and brackish water animals. I. Temperature. Oceanogr. Mar. Biol. Ann. Rev., 1: 281-239.

Kinne, O. -1964 . The effects of temperature and salinity on marine and brackish water animals. II. Salinity and temperature salinity combinations. Oceanogr. Mar. Biol. Ann. Rev., 2: 281-339.

Marfenin, N.N. - 1983. A new species of genus Cordylophora (Hydrozoa, Clavidae) from the Black Sea. Zool. Z., LXII, 11: 1732-1734 (In Russian).

Mayer, A.G. - 1904. Medusae of the Bahamas. Mem. Nat. Sci. Mus. Brooklin Inst. Arts. Sci. 1(2): 1-33.

Mayer, A.G. - 1910. Medusae of the world. I. The Hydromedusae. Washington Publ.Carnegie Inst.: 1-230; I-XV.

Millard, N.A. - 1959. Hydrozoa from ships' hulls and experimental plates in Cape Town docks. Ann. S. Afr. Mus. 45: 239-256.

Millard, N.A. - 1975. Monograph on the Hydroida of Southern Africa. Ann. S. Afr. Mus. 68: 1-513.

Morri, C. - 1980. Alcune osservazioni sulle Cordylophora italiane (Cnidaria, Hydroida). Atti V Conv. Gr. "G. Gadio" - Varese, Maggio: 151-170

Morri, C. - 1981. Idrozoi lagunari. Guide per il riconoscimento delle specie animali del acque lagunari e costiere italiane. Consiglio Nazionale delle Ricerche, Roma, AQ/1/94, 6: 1-105.
Motz-Kossowska, S. - 1905. Contribution a la connaissance des hydraires de la Mediterranee occidentale. I. - Hydraires gymnoblastiques. Arch. Zool. Exper. Gen., 4me serie, 3: 39-98.

Negoro, K. - 1982. The plankton of Lake Biwa. The Shiga Prefectural Institutwe of public health and environmental science

Ovanesyan, I.G. and V.G. Kuznetsova. - 1995. The karyotype of Hydra vulgaris Pall. and the survey of the karyotype data on other Hydridae species (Cnidaria, Hydrozoa, Hydroidea, Hydridae). In: Stepannjants, S.D. (ed.). Cnidaria. Modern and perspective investigations. II. Trudi Zool.Inst., 261: 95-102.

Petersen, K.W. 1990. Evolution and taxonomy in capitate hydroids and medusae (Cnidaria: Hydrozoa). Zool. J. Linn. Soc., 100: $101-231$.

Picard, J. - 1958. Origines et affinites de la faune d'hydropolypes (gymnoblastes et calyptoblastes) et d'hydromeduses (anthomeduses et leptomeduses) de la Mediterranee. Rapp. Proc.-Verb. Reun., Com. Internat. Explor. Scient. Mer Mediterranee, 14: 187-199.

Schuchert, P. - 1996. The Marine Fauna of New Zealand: Athecate Hydroids and their Medusae (Cnidaria: Hydrozoa). New Zealand Oceanogr. Inst. Mem., 106: $150 \mathrm{p}$.

Stechow, E. - 1919. Zur kenntniss der Hydroidenfauna des Mittelmeeres, Amerikas und anderer Gebiete, nebst Angaben ueber einige Kirchenpauer'sche Typen von Plumulariden. Zool. Jahrb., 42: 1- 172.

Stechow, E. - 1921. Neue Genera und Species von Hydrozoen und anderen Evertebraten. Archiv fur Naturgesch., 87: 248-265.

Stechow, E. - 1923. Zur Kenntnis der Hydroidenfauna des Mittelmeeres, Americas und anderer Gebiete. II. Teil. Zool. Jahrb. Abt. Syst. Oekol. Geogr. Tiere., 47: 29-247.

Stepanjants, S. and A. Svoboda. - 1999. Genera and species of Antarctic Corymorphinae with the discussion concerning structure of this subfamily. In: Ryss, A. and Sinev, S. (eds.). Zoological Sessions Annual Reports of Zoological Institute, Russian Academy of Sciences, 1998. Trudy (Proceedings) Zool. Inst. RAS. 281: 47-54.

Thiel, H. - 1962. Clavopsella quadranularia nov. spec. (Clavopsellidae nov. fam.), ein neuer hydroidpolyp aus der Ostsee und seine phylogenetishe bedeutung. J. Morph. Oekol. Tiere. 51: 227-260.

Wedler, E. and R. Larson. - 1986. Athecate hydroids from Puerto Rico and the Virgin Islands. Stud. Neotropical Fauna Envir. 21 69-101.

Weismann, A. - 1883. Die Entstehung der Sexualzellen bei den Hydromedusen. Zugleich ein Beitrag zur Kentniss des Baues und der Lebenserscheinungen dieser gruppe. Text. Atlas. Jena Verlag Gustav Fisher: 1-295, Taf. I-XXIV. 